a selective medium. J Clin Pathol 1981;34:642-4.

${ }^{4}$ Nunez-Montiel OL, Thompson FS, Dowell VR. Norleucinetyrosine broth for rapid identification of Clostridium difficile by gas liquid chromatography. J Clin Microbiol 1983;17:382-5.

s Potvliege C, Labbe M, Yourassowsky E. Gas liquid chromatography as screening test for Clostridium difficile. Lancet 1981;ii: 1105.

- Makin T. Rapid identification of Clostridium difficile by direct detection of volatile organic acids from primary isolation media. J Clin Pathol 1984;37:711-2.

' Elsden SR, Hilton MG, Waller JM. The end products of the metabolism of aromatic amino acids by Clostridia. Arch Microbiol 1976; 107:283-8.

Requests for reprints to: Dr JD Berg, Department of Clinical Chemistry, East Birmingham Hospital, Bordesley Green East, Birmingham B9 5ST, England.

\section{Demonstration of Mycobacterium tuberculosis in epoxy resin sections by the Ziehl-Neelsen technique}

\author{
KE BRASSIL From the Department of Histo- \\ pathology, RGH Greenslopes, Queensland, \\ Australia
}

The Ziehl-Neelsen technique is the fundamental staining procedure for demonstrating acid fast bacilli. But the results obtained with this technique on semithin sections of tissue embedded in epoxy resin have not been satisfactory. Adequate staining of epoxy embedded tissue has required either oxidation of the section with periodic acid ${ }^{1}$ or hydrogen peroxide ${ }^{2}$ without the removal of resin, or extraction of the resin with sodium ethoxide ${ }^{3}$ or bromine vapour. ${ }^{4}$ These two approaches have been combined, the latter approach being essential because of the resin's affinity for basic fuchsin.

\section{Material and methods}

TISSUE FIXATION AND EMBEDDING

Human tissue previously fixed in $10 \%$ neutral buffered formalin and known to contain Mycobacterium tuberculosis, $M$ leprae, and bacteria was cleared in acetone, embedded in epoxy resin (TAAB, Polybed, Polaron, Epon), and cut at $4 \mu \mathrm{m}$.

\section{RESIN SOLVENTS}

Two agents were used: saturated alcoholic sodium hydroxide for $15 \mathrm{~min}$ followed by washes in alcohol and water, and bromine vapour. A $2 \mathrm{ml}$ ampoule of bromine was scored, and broken by a glass rod in a Coplin jar under a fumehood. The Coplin jar was closed. When the bromine vapour reached maximum concentration a slide was quickly inserted and the jar closed again. After 30-60 s the slide was removed and rapidly washed in two changes of acetone and then placed in water. Maximum concentration of bromine vapour is an essential factor for success with this technique.

\section{OXIDISING AGENTS}

The oxidising agents evaluated were $5 \%$ chromic acid, $0.5 \%$ and $1 \%$ potassium permanganate, $3 \%$ hydrogen peroxide, and both $1 \%$ and $10 \%$ periodic acid. Tissue sections were exposed to the above oxidising agents for periods of $5,10,15$ and $20 \mathrm{~min}$ Chromic acid was also applied for $1 \mathrm{~h}$ and $10 \%$ periodic acid for $4 \mathrm{~h}$. All reactions took place at $22^{\circ} \mathrm{C}$. The $1 \%$ and $10 \%$ periodic acid were also applied at $60^{\circ} \mathrm{C}$.

\section{STAINING}

After oxidation the sections were washed well in running water. Ziehl-Neelsen's carbol fuchsin was applied, heated until steaming, and allowed to stain for $10 \mathrm{~min}$. The sections were decolorised with acid alcohol and counterstained with $0.1 \%$ malachite green, dried, and coverslipped.

\section{Results}

Only the bromine vapour together with $10 \%$ periodic acid oxidation for $5-10 \mathrm{~min}$ at $22^{\circ} \mathrm{C}$ gave a strong acid alcohol fast reaction. The result was independent of the brand of epoxy resin used. Saturated ethanolic sodium hydroxide with the same oxidation was essentially negative. If the sections were allowed to remain in the bromine vapour for more than $60 \mathrm{~s}$, the tubercle bacilli rapidly lost colour.

Five per cent chromic acid, $0.5 \%$ and $1 \%$ potassium permanganate, $3 \%$ hydrogen peroxide, and $1 \%$ periodic acid (also at $60^{\circ} \mathrm{C}$ ) failed to intensify the Ziehl-Neelsen stain. The $10 \%$ periodic acid at $22^{\circ} \mathrm{C}$ was positive after $15 \mathrm{~min}$ but the background was pink. This colour intensified with time and made the detection of the bacilli impossible. The $10 \%$ periodic acid at $60^{\circ} \mathrm{C}$ for 5 min produced a positive result but the bacilli and tissue showed structural disruption.

$M$ leprae and bacteria were used as controls and 
they remained unstained in all the tests. It should be noted that the sections tended to come off the slides at $60^{\circ} \mathrm{C}$ on all occasions.

\section{Discussion}

The properties necessary for the acid alcohol fastness of tubercle bacilli are an intact cell or the lipoidal portion of the cell mycolic acid or both. ${ }^{5}$

$\mathrm{Nyka}^{67}$ has previously shown that periodic acid oxidation of tubercle bacilli during fixation and on paraffin sections caused them to stain strongly by the methenamine silver and Ziehl-Neelsen techniques and that without oxidation the stain was poor or negative. Whether the stain is intensified by the oxidation of the ethylene groups of the organisms' unsaturated lipids ${ }^{8}$ or by the oxidation of the polysaccharide constituents of the bacillus to form aldehydes stainable by basic fuchsin is not known.

In this experiment, which was performed with epoxy resin sections, the same results occurred. It was also found that bromination for longer than $60 \mathrm{~s}$ produced a negative stain which could not be reversed by oxidation. Bromination for $30-60 \mathrm{~s}$ and subsequent oxidation produced a positive result. It follows that it is essential the tissue remains in the bromine vapour for the shortest possible effective time.

It seems probable that mycolic acid is extracted by the presently used resin solvent ethanolic sodium hydroxide or blocked in the case of bromine. ${ }^{9}$ It seems probable that the positive result after oxidation is dependent on the structure of the intact cell rather than the mycolic acid.

I am grateful for the excellent technical assistance of $\mathrm{J}$ Kan and J Holzl.

\section{References}

' Chang SC. Haematoxylin-eosin staining of plastic-embedded tissue sections. Arch Pathol 1972;93:344-51.

${ }^{2}$ Aparicio SR, Marsden P. Application of standard microanatomical staining methods to epoxy resin-embedded sections. J Clin Pathol 1969; 22: 589-92.

${ }^{3}$ Lane BP, Europa DL. Differential staining of ultra thin sections of epon-embedded tissues for light microscopy. $J$ Histochem Cytochem 1965; 13:579-82.

4 Yenson J. Removal of epoxy resin from histological sections following halogenation. Stain Technol 1968;43:344-6.

${ }^{5}$ Berg JW. Acid-fastness as a histochemical test. J Histochem Cytochem 1953;1:436-41.

- Nyka W. Studies on Mycobacterium tuberculosis in lesions of the human lung. A new method of staining tubercle bacilli in tissue sections. Am Rev Resp Dis 1963;88:670-9.

' Nyka W. Method for staining both acid-fast and chromophobic tubercle bacilli with carbolfuchsin. J Bacteriol 1967;93:145860 .

${ }^{8}$ Wolman M. The lipids stained by the periodic acid-Schiff technic. Stain Technol 1956;31:241-5.

${ }^{9}$ Harada K. The nature of mycobacterial acid-fastness. Stain Technol 1976;51:255-60.

Requests for reprints to: KE Brassil, Department of Histopathology, RGH Greenslopes, Queensland, Australia.

\section{Micromodified cytomegalovirus antibody screening test}

\author{
SM HENRY, AM RAMIREZ, DG WOODFIELD Auckland \\ Blood Transfusion Centre, Auckland, New Zealand
}

Recent increased interest in post-transfusion cytomegalovirus (CMV) infections in young infants ${ }^{1}$ and immunosuppressed patients ${ }^{2}$ has resulted in clinical requests for blood screened for CMV antibodies. ${ }^{3}$ Detection of these antibodies is possible by a variety of tests, including complement fixation, ${ }^{4}$ fluorescent antibody techniques, ${ }^{5}$ enzyme linked immunoabsorbent assays, ${ }^{6}$ indirect haemagglutination tests, ${ }^{7}$ or radioimmunoassay. ${ }^{8}$ One procedure which is particularly attractive to blood transfusion centres is the indirect haemagglutination assay, which utilises well known serological techniques and is adaptable to rapid screening procedures.

Although a commercial indirect haemagglutination assay kit is available, ${ }^{9}$ its cost precludes its use for routine blood donor screening. We report our experience with a micromodification of the test which makes the method economical while maintaining sensitivity and specificity.

\section{Material and methods}

CMV indirect haemagglutination assay kits (Cetus Corporation, California, USA) were used according to the manufacturer's directions. In brief, human group $O$ cells are supplied sensitised with CMV antigen. These cells are incubated with test serum in V-bottomed microtitre plates, and the agglutination patterns are observed. Results may be read after 90 min and settling patterns remain constant for up to $18 \mathrm{~h}$.

The procedure was modified to enable the test to be performed in microtissue culture trays (Nunclon 